\title{
Marispirillum indicum gen. nov., sp. nov., isolated from a deep-sea environment
}

Correspondence

Zongze Shao

shaozz@163.com

\author{
Qiliang Lai, Jun Yuan, Li Gu and Zongze Shao
}

Key Laboratory of Marine Biogenetic Resources, Third Institute of Oceanography, State Oceanic Administration, Xiamen 361005, PR China

\begin{abstract}
A taxonomic study was carried out on strain $\mathrm{B} 142^{\top}$, which was isolated from a crude-oildegrading microbial consortium via enrichment with deep water from the Indian Ocean. Cells of the isolate were Gram-negative, oxidase-negative, catalase-positive, helical in shape, motile by means of polar flagella (three per cell) and moderately halophilic. Growth was observed at salinities of $0.5-12 \%$ and at temperatures of $10-41{ }^{\circ} \mathrm{C}$. The micro-organism was capable of denitrification, but was unable to degrade Tween 80 or gelatin. The predominant fatty acids were $\mathrm{C}_{16: 1} \omega 7 c$ and/or iso- $\mathrm{C}_{15: 0} 2-\mathrm{OH}(6.4 \%), \mathrm{C}_{16: 0}(15.7 \%), \mathrm{C}_{18: 1} \omega 7 c(45 \%), \mathrm{C}_{18: 0}(6.8 \%)$ and $\mathrm{C}_{19: 0} \omega 8 \mathrm{c}$ cyclo $(6.7 \%)$. The $\mathrm{G}+\mathrm{C}$ content of the chromosomal DNA was $67.3 \mathrm{~mol} \%$.

Comparisons of $16 \mathrm{~S}$ rRNA gene sequences showed that strain $\mathrm{B}_{142^{\top}}$ was most closely related to the type strains of two Insolitispirillum peregrinum subspecies (93.0-93.1\% sequence similarity), two Novispirillum itersonii subspecies (92.8-92.9\%) and Caenispirillum bisanense $(91.7 \%)$; sequence similarities with respect to other taxa were below $90.5 \%$. Phylogenetic analyses based on $16 \mathrm{~S}$ rRNA gene sequences showed that strain $B 142^{\top}$ formed a distinct evolutionary lineage within the family Rhodospirillaceae. Strain $B 142^{\top}$ was distinguishable from phylogenetically related genera with regard to several phenotypic properties. On the basis of phenotypic and phylogenetic data, therefore, strain $B 142^{\top}$ represents a novel genus and species, for which the name Marispirillum indicum gen. nov., sp. nov. is proposed. The type strain is $B 142^{\top}$ $\left(=\right.$ CCTCC AB $208225^{\top}=$ LMG $24627^{\top}=$ MCCC 1 A01235 $\left.5^{\top}\right)$.
\end{abstract}

In an attempt to investigate crude-oil-degrading bacteria in the deep water of the Indian Ocean, many bacterial strains were isolated and characterized taxonomically. Comparative $16 \mathrm{~S}$ rRNA gene sequence analysis showed that one isolate, designated strain $\mathrm{B} 142^{\mathrm{T}}$, formed a deep branch within the phylogeny of the family Rhodospirillaceae. Accordingly, it was subjected to further taxonomic study, using a polyphasic approach that included the determination of its phenotypic properties and a detailed phylogenetic analysis based on $16 \mathrm{~S}$ rRNA gene sequences.

Seawater was sampled from a depth of $1714 \mathrm{~m}(1400 \mathrm{~m}$ above the sea floor) at the IR-CTD13 site $\left(69.7944^{\circ} \mathrm{E}\right.$ $24.2822^{\circ} \mathrm{S}$ ) on the south-west Indian Ridge in December 2005 during the DY-105A cruise of the R/V Da-Yang YiHao. The seawater sample was used for an enrichment with crude oil as the carbon and energy source. Enrichment for the oil-degrading bacterial consortium was conducted on board, immediately after sampling. In the laboratory

The GenBank/EMBL/DDBJ accession number for the 16S rRNA gene sequence of strain $B 142^{\top}$ is EU642410.

Transmission electron micrographs of cells of strain $B 142^{\top}$ and a table showing the cellular fatty acid contents of strain $B 142^{\top}$ and related taxa are available as supplementary material with the online version of this paper.
(2 months later), $1 \mathrm{ml}$ enrichment culture was transferred into $100 \mathrm{ml}$ fresh MM medium (see below), incubated at $28{ }^{\circ} \mathrm{C}$ with shaking at 160 r.p.m. The $\mathrm{MM}$ medium consisted of $\mathrm{NH}_{4} \mathrm{NO}_{3}$ at $1.0 \mathrm{~g} \mathrm{l}^{-1}, \mathrm{KH}_{2} \mathrm{PO}_{4}$ at $0.5 \mathrm{~g} \mathrm{l}^{-1}$, $\mathrm{FeSO}_{4} .7 \mathrm{H}_{2} \mathrm{O}$ (filtered through a $0.22 \mu \mathrm{m}$ film) at $2.8 \mathrm{mg} \mathrm{l}^{-1}$ and $1 \%(\mathrm{v} / \mathrm{v})$ crude oil, prepared with aged deep seawater. The medium was sterilized at $121{ }^{\circ} \mathrm{C}$ for 20 min and the crude oil and the $\mathrm{KH}_{2} \mathrm{PO}_{4}$ stock solution were sterilized separately under the same conditions. Sequential transfers were performed three times at intervals of 2 weeks. Bacteria were isolated using the plate screening method on 216L medium (containing, per litre seawater: $\mathrm{CH}_{3} \mathrm{COONa}, 1.0 \mathrm{~g}$; tryptone, $10.0 \mathrm{~g}$; yeast extract, $2.0 \mathrm{~g}$; sodium citrate, $0.5 \mathrm{~g} ; \mathrm{NH}_{4} \mathrm{NO}_{3}, 0.2 \mathrm{~g} ; \mathrm{pH}$ 7.5). The $216 \mathrm{~L}$ medium was used for all studies of strain $\mathrm{B} 142^{\mathrm{T}}$, except where indicated otherwise.

The general cell morphology was studied using an inverted microscope (IX70; Olympus) with a 1-day-old culture of strain $\mathrm{B} 142^{\mathrm{T}}$ grown on $216 \mathrm{~L}$ agar. For electron microscopy, exponential phase cells were harvested, suspended and absorbed onto a carbon-coated Formvar grid, then stained with phosphotungstic acid (Liu \& Shao, 2005); the result is shown in Supplementary Fig. S1 (available in IJSEM Online). The Gram reaction, catalase and oxidase activities, 
lipase activity (Tween 80) and amylase activity were determined using the methods described by Liu \& Shao (2005). The optimal growth temperature was determined over the temperature range $4-55{ }^{\circ} \mathrm{C}$ in $216 \mathrm{~L}$. Tolerance of $\mathrm{NaCl}$ was tested by using Luria-Bertani medium (Sambrook et al., 1989) supplemented with $\mathrm{NaCl}$ at the following concentrations: $0,0.5,1,2,3,4,5,6,7,8,9,10$, $12,15,18$ and $20 \%(\mathrm{w} / \mathrm{v})$. Antibiotic-susceptibility tests were performed using the disc diffusion method as described by Shieh et al. (2003). Other biochemical tests were carried out with API 20NE and API ZYM strips (bioMérieux) according to the manufacturer's instructions, and with the Biolog GN2 MicroPlate panel as described by Ivanova et al. (1998). The $\mathrm{G}+\mathrm{C}$ content of the chromosomal DNA was determined according to the methods described by Mesbah \& Whitman (1989) using reversedphase HPLC. These results are given in the species description and in Table 1.

Fatty acids from whole cells grown on 216L plate medium at $28{ }^{\circ} \mathrm{C}$ for $48 \mathrm{~h}$ were extracted, saponified and esterified; gas chromatography analysis of the fatty acid methyl esters was then performed according to the instructions of the MIDI system (Sasser, 1997). The major fatty acids of strain

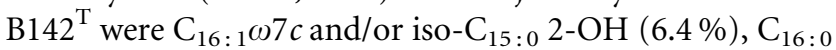
$(15.7 \%), \mathrm{C}_{18: 1} \omega 7 c(45.0 \%), \mathrm{C}_{18: 0}(6.8 \%)$ and $\mathrm{C}_{19: 0} \omega 8 c$ cyclo $(6.7 \%)$.

Genomic DNA was prepared according to the method of Ausubel et al. (1995) and the 16S rRNA gene was amplified using PCR with primers that have been described previously (Liu \& Shao, 2005). Sequences of related taxa were obtained from the GenBank database. A phylogenetic analysis was performed using MEGA, version 4 (Tamura et al., 2007), after multiple alignment of the data by DNAMAN (version 5.1; Lynnon Biosoft). Distance options according to the Kimura two-parameter model (Kimura, 1980) and clustering with the neighbour-joining method of Saitou \& Nei (1987) and the minimum-evolution method of Rzhetsky \& Nei (1992, 1993) were determined by using bootstrap percentages based on 1000 replications. The minimum-evolution data are not shown here, as the clustering obtained was similar to that found with the neighbour-joining method.

An almost-complete 16S rRNA gene sequence (1450 nt) was determined for strain $\mathrm{B} 142^{\mathrm{T}}$. A phylogenetic analysis of strain $\mathrm{B} 142^{\mathrm{T}}$ indicated that it belonged to the family Rhodospirillaceae (Fig. 1). In the phylogenetic tree based on the neighbour-joining algorithm, strain $\mathrm{B} 142^{\mathrm{T}}$ was positioned in the phylogenetic clade comprising type strains of subspecies of Insolitispirillum peregrinum and Novispirillum itersonii and Caenispirillum bisanense, with which the strain exhibited the highest 16S rRNA gene sequence similarities (91.7-93.1\%). The sequence similarity values between strain $\mathrm{B} 142^{\mathrm{T}}$ and the other species used in the phylogenetic analysis were in the range $85.6-90.4 \%$ (Fig. 1). In addition, when subjected to BLAST analysis (http://blast.ncbi.nlm. nih.gov/blast), strain $\mathrm{B} 142^{\mathrm{T}}$ showed the highest $16 \mathrm{~S}$ rRNA gene sequence similarity $(97.1 \%)$ with an uncultured
Table 1. Characteristics that serve to differentiate strain $\mathrm{B} 142^{\top}$ from related genera

Strains: $1, \mathrm{~B} 142^{\mathrm{T}}$ (Marispirillum indicum gen. nov., sp. nov.); 2, $N$. itersonii subsp. itersonii LMG $4337^{\mathrm{T}} ; 3$, N. itersonii subsp. nipponicum LMG $7370^{\mathrm{T}}$; 4, I. peregrinum subsp. peregrinum LMG $4340^{\mathrm{T}} ; 5$, I. peregrinum subsp. integrum LMG $5407^{\mathrm{T}} ; 6$, C. bisanense $\mathrm{K} 92^{\mathrm{T}}$. Data for 2-6 were from Yoon et al. (2007a, b). +, Positive; -, negative; w, weak.

\begin{tabular}{|c|c|c|c|c|c|c|}
\hline Characteristic & 1 & 2 & 3 & 4 & 5 & 6 \\
\hline Oxidase & - & + & + & + & + & + \\
\hline No. of flagella & $1-3$ & 1 & 1 & 1 & 1 & 1 \\
\hline $\begin{array}{l}\text { Maximum growth } \\
\text { temperature }\left({ }^{\circ} \mathrm{C}\right)\end{array}$ & 41 & 43 & 41 & 39 & 39 & 47 \\
\hline Nitrate reduction & + & + & + & - & - & + \\
\hline $\begin{array}{l}\text { Anaerobic growth with } \\
\mathrm{KNO}_{3}\end{array}$ & + & + & + & - & - & + \\
\hline \multicolumn{7}{|l|}{ Hydrolysis of: } \\
\hline Starch & - & - & - & - & - & + \\
\hline Tween 80 & - & - & - & - & - & + \\
\hline \multicolumn{7}{|l|}{$\begin{array}{l}\text { Enzyme activity (API } \\
\text { ZYM) }\end{array}$} \\
\hline Acid phosphatase & - & $\mathrm{w}$ & - & - & $\mathrm{w}$ & - \\
\hline Alkaline phosphatase & + & + & + & + & + & - \\
\hline Esterase $(\mathrm{C} 4)$ & - & + & + & - & - & + \\
\hline Esterase lipase (C8) & - & + & + & - & - & + \\
\hline $\begin{array}{l}\text { Leucine } \\
\text { aminopeptidase }\end{array}$ & + & $\mathrm{w}$ & - & - & - & - \\
\hline $\begin{array}{l}\text { Naphthol-AS-BI- } \\
\text { phosphoamidase }\end{array}$ & w & + & + & + & + & $\mathrm{w}$ \\
\hline$\beta$-Glucosidase & - & - & - & + & + & - \\
\hline \multicolumn{7}{|l|}{ Susceptibility to: } \\
\hline Ampicillin & - & + & + & + & + & + \\
\hline Carbenicillin & + & - & - & + & + & + \\
\hline Lincomycin & - & - & + & - & - & - \\
\hline Penicillin G & - & + & + & + & + & + \\
\hline Polymyxin B & - & $\mathrm{w}$ & - & + & + & + \\
\hline Tetracycline & - & + & + & + & + & + \\
\hline \multicolumn{7}{|l|}{ Utilization of: } \\
\hline Glycerol & - & - & + & - & - & + \\
\hline Citrate & - & - & - & - & - & + \\
\hline D-Fructose & - & + & + & + & + & - \\
\hline Glycogen & + & - & - & - & - & - \\
\hline $\begin{array}{l}\text { DNA G }+C \text { content } \\
(\mathrm{mol} \%)\end{array}$ & 67.3 & 63.2 & 64.7 & 62.4 & 62.3 & 70 \\
\hline
\end{tabular}

proteobacterial clone isolated from subsurface water from the Kalahari Shield in South Africa (GenBank accession no. DQ234645.1; Gihring et al., 2006).

Strain $\mathrm{B} 142^{\mathrm{T}}$ is oxidase-negative and the cells have bipolar flagella: thus, it is distinguishable from $I$. peregrinum, $N$. itersonii and C. bisanense, which are oxidase-positive and consist of cells with single polar flagella. The fatty acid profiles of strain $\mathrm{B} 142^{\mathrm{T}}$ were similar to those of $I$. peregrinum, $N$. itersonii and $C$. bisanense (see Supplementary Table S1, available in IJSEM Online). However, strain $\mathrm{B} 142^{\mathrm{T}}$ showed minor differences in the proportions of several fatty acids and only strain $\mathrm{B} 142^{\mathrm{T}}$ 


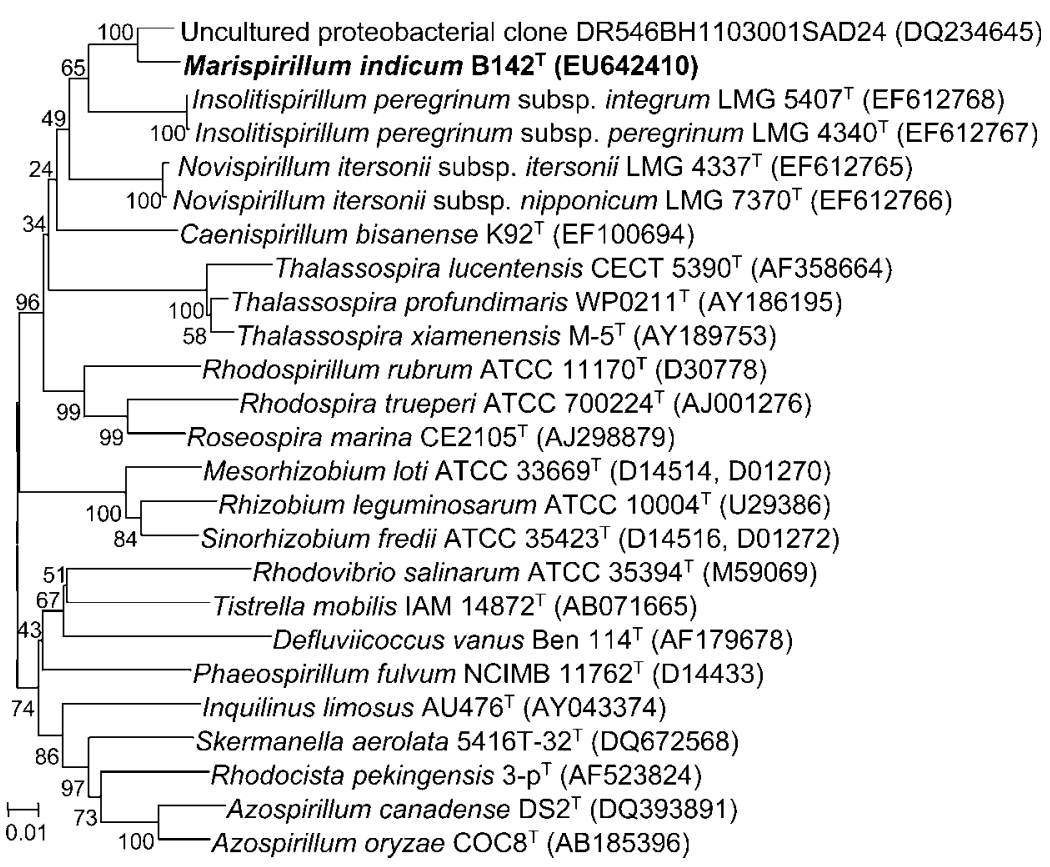

Fig. 1. Neighbour-joining phylogenetic tree, based on 16S rRNA gene sequences, showing the positions of strain $B 142^{\top}$ and representatives of some related taxa in the family Rhodospirillaceae. Bootstrap percentages (based on 1000 replications) are shown at branch points. Bar, 0.01 nucleotide substitution rate $\left(K_{\text {nuc }}\right)$ units. contained $\mathrm{C}_{17: 0}$ cyclo $(4.7 \%$ ) (see Supplementary Table S1 in IJSEM Online). Strain $\mathrm{B} 142^{\mathrm{T}}$ was also distinguishable from I. peregrinum, $N$. itersonii and C. bisanense in terms of several phenotypic properties, as shown in Table 1 . The low levels of $16 \mathrm{~S}$ rRNA gene sequence similarity between strain $\mathrm{B} 142^{\mathrm{T}}$ and all other members of the family Rhodospirillaceae, together with the differential phenotypic properties, suggest that strain $\mathrm{B} 142^{\mathrm{T}}$ represents a novel genus and species within the family Rhodospirillaceae, for which the name Marispirillum indicum gen. nov., sp. nov. is proposed.

\section{Description of Marispirillum gen. nov.}

Marispirillum (Ma.ri.spi.ril'lum. L. neut. n. mare the sea; N.L. dim. neut. n. spirillum a small spiral; N.L. neut. n. Marispirillum a small spiral of the sea).

Cells are Gram-negative, oxidase-negative, catalase-positive and helical in shape. Major fatty acids are $\mathrm{C}_{16: 1} \omega 7 \mathrm{c}$ and/or iso- $\mathrm{C}_{15: 0} 2-\mathrm{OH}, \mathrm{C}_{16: 0}, \mathrm{C}_{18: 1} \omega 7 c, \mathrm{C}_{18: 0}$ and $\mathrm{C}_{19: 0} \omega 8 c$ cyclo. The type species is Marispirillum indicum.

\section{Description of Marispirillum indicum sp. nov.}

Marispirillum indicum (in.di'cum. L. neut. adj. indicum Indian, referring to the Indian Ocean, where the strain was isolated).

Exhibits the following properties in addition to those given in the genus description. Cells are 1.9-2.7 $\mu \mathrm{m}$ long and $0.6-0.7 \mu \mathrm{m}$ wide and motile, by means of $1-3$ flagella (one flagellum at each pole). Positive for denitrification, lipase (Tween 80 ), amylase, urease, gelatinase, arginine dihydrolase and indole production. On $216 \mathrm{~L}$ agar plates, colonies are smooth, grey and yellowish with regular edges, 1-2 mm in diameter and slightly raised in the centre after $72 \mathrm{~h}$ incubation at $28{ }^{\circ} \mathrm{C}$. Moderately halophilic, growing with $\mathrm{NaCl}$ at $0.5-12 \%$ (optimally at $2-8 \%$ ). Grows at $10-41{ }^{\circ} \mathrm{C}$ (optimally at $25-37{ }^{\circ} \mathrm{C}$ ), but not at 4 or $45{ }^{\circ} \mathrm{C}$, within 7 days. Unable to ferment glucose. Sensitive to the following antibiotics (Oxoid) ( $\mu$ g per disc): carbenicillin (100), chloramphenicol (30), ciprofloxacin (5), erythromycin (15), gentamicin (10), kanamycin (30), minocycline (30), neomycin (10), norfloxacin (10), ofloxacin (5), rifampicin (5), ceftriaxone (30), streptomycin (10) and doxycycline (30). Resistant to the following antibiotics ( $\mu \mathrm{g}$ per disc, unless indicated otherwise): ampicillin (10), cefalexin (30), cefazolin (30), cefoperazone (30), cefradin (30), clindamycin (2), co-trimoxazole (25), furazolidone (15), lincomycin (2), metronidazole (5), oxacillin (1), penicillin $\mathrm{G}(10)$, piperacillin (100), polymyxin B (30 U), tetracycline (30) and vancomycin (30). In the API ZYM test, positive for alkaline phosphatase and leucine aminopeptidase, weakly positive for naphthol-AS-BI-phosphoamidase and negative for acid phosphatase, cystine aminopeptidase, esterase (C4), esterase lipase (C8), lipase (C14), $N$-acetyl- $\beta$-glucosaminidase, trypsin, valine aminopeptidase, $\alpha$-chymotrypsin, $\alpha$-fucosidase, $\alpha$-galactosidase, $\alpha$-glucosidase, $\alpha$-mannosidase, $\beta$-galactosidase, $\beta$-glucosidase and $\beta$-glucuronidase. In the API $20 \mathrm{NE}$ test, positive for utilization of potassium gluconate and malic acid, but not D-glucose, L-arabinose, D-mannose, D-mannitol, $N$ acetylglucosamine, maltose, capric acid, adipic acid, trisodium citrate or phenylacetic acid. In the Biolog GN2 system (96 substrates), positive for L-alaninamide, L-alanine, bromosuccinic acid, DL-lactic acid, DL- $\alpha$-glycerol phosphate, D-galactonic acid lactone, D-gluconic acid, D-psicose, glycogen, L-glutamic acid, L-phenylalanine, L-proline, L-threonine, pyruvic acid methyl ester, succinic acid monomethyl ester, p-hydroxyphenylacetic acid, propionic acid, succin- 
amic acid, succinic acid, Tween 40, $\alpha$-hydroxybutyric acid, $\alpha$ ketobutyric acid, $\alpha$-ketoglutaric acid, $\alpha$-ketovaleric acid, $\beta$ hydroxybutyric acid and $\gamma$-hydroxybutyric acid. The DNA $\mathrm{G}+\mathrm{C}$ content of the type strain is $67.3 \mathrm{~mol} \%$.

The type strain, B142 ${ }^{\mathrm{T}}$ (=CCTCC AB $208225^{\mathrm{T}}=\mathrm{LMG}$ $24627^{\mathrm{T}}=$ MCCC $1 \mathrm{~A} 01235^{\mathrm{T}}$ ), was isolated from deep-water samples from the Indian Ocean.

\section{Acknowledgements}

This work was financially supported by the National Infrastructure of Natural Resources for Science and Technology Program of China (no. 2005DKA21209), the COMRA program (no. DYXM115-02-2-05) and the National Basic Research Program of China (no. 2004CB719601).

\section{References}

Ausubel, F. M., Brent, R., Kingston, R. E., Moore, D. D., Seidman, J. G., Smith, J. A. \& Struhl, K. (editors) (1995). Short Protocols in Molecular Biology: a Compendium of Methods from Current Protocols in Molecular Biology, 3rd edn. New York: Wiley.

Gihring, T. M., Moser, D. P., Lin, L.-H., Davidson, M., Onstott, T. C., Morgan, L., Milleson, M., Kieft, T. L., Trimarco, E. \& other authors (2006). The distribution of microbial taxa in the subsurface water of the Kalahari Shield, South Africa. Geomicrobiol J 23, 415-430.

Ivanova, E. P., Kiprianova, E. A., Mikhailov, V. V., Levanova, G. F., Garagulya, A. D., Gorshkova, N. M., Vysotskii, M. V., Nicolau, D. V., Yumoto, N. \& other authors (1998). Phenotypic diversity of Pseudoalteromonas citrea from different marine habitats and emendation of the description. Int J Syst Bacteriol 48, 247-256.

Kimura, M. (1980). A simple method for estimating evolutionary rates of base substitutions through comparative studies of nucleotide sequences. J Mol Evol 16, 111-120.
Liu, C. \& Shao, Z. (2005). Alcanivorax dieselolei sp. nov., a novel alkane-degrading bacterium isolated from sea water and deep-sea sediment. Int J Syst Evol Microbiol 55, 1181-1186.

Mesbah, M. \& Whitman, W. B. (1989). Measurement of deoxyguanosine/thymidine ratios in complex mixtures by high-performance liquid chromatography for determination of the mole percentage guanine + cytosine of DNA. J Chromatogr 479, 297-306.

Rzhetsky, A. \& Nei, M. (1992). A simple method for estimating and testing minimum-evolution trees. Mol Biol Evol 9, 945-967.

Rzhetsky, A. \& Nei, M. (1993). Theoretical foundation of the minimum-evolution method of phylogenetic inference. Mol Biol Evol 10, 1073-1095.

Saitou, N. \& Nei, M. (1987). The neighbor-joining method: a new method for reconstructing phylogenetic trees. Mol Biol Evol 4, 406425.

Sambrook, J., Fritsch, E. F. \& Maniatis, T. (1989). Molecular Cloning: a Laboratory Manual, 2nd edn. Cold Spring Harbor, NY: Cold Spring Harbor Laboratory.

Sasser, M. (1997). Identification of bacteria by gas chromatography of cellular fatty acids, MIDI Technical Note 101. Newark, DE: MIDI Inc.

Shieh, W. Y., Chen, Y.-W., Chaw, S.-M. \& Chiu, H.-H. (2003). Vibrio ruber sp. nov., a red, facultatively anaerobic, marine bacterium isolated from sea water. Int J Syst Evol Microbiol 53, 479-484.

Tamura, K., Dudley, J., Nei, M. \& Kumar, S. (2007). MEGA4: molecular evolutionary genetics analysis (MEGA) software version 4.0. Mol Biol Evol 24, 1596-1599.

Yoon, J. H., Kang, S. J., Park, S. \& Oh, T. K. (2007a). Caenispirillum bisanense gen. nov., sp. nov., isolated from sludge of a dye works. Int $J$ Syst Evol Microbiol 57, 1217-1221.

Yoon, J. H., Kang, S. J., Park, S., Lee, S. Y. \& Oh, T. K. (2007b). Reclassification of Aquaspirillum itersonii and Aquaspirillum peregrinum as Novispirillum itersonii gen. nov., comb. nov. and Insolitispirillum peregrinum gen. nov., comb. nov. Int J Syst Evol Microbiol 57, 2830-2835. 